\section{Acute opacification of hydrophobic acrylic intraocular lens during implantation: result of temperature variation}

\author{
Opacificação aguda de lente intraocular acrílica \\ hidrofóbica durante a implantação: resultado da \\ variação de temperatura
}

To the editor:

Implantation of acrylic foldable intraocular lenses (IOLs) seems to be a safe and effective method for microincision cataract surgery. Although it is effective, this method can result in some complications or unexpected events during implantation and follow-up. Delayed opacification of IOLs is known as pseudocataract ${ }^{(1,2)}$, and intraoperative clouding of acrylic hydrophilic IOLs has been reported ${ }^{(3)}$. However, to the best of our knowledge, acute opacification during the implantation of hydrophobic IOLs due to temperature change has not yet been reported. Herein, we present three cases of intraoperative acute opacification of hydrophobic IOLs due to temperature change.

Case 1: A 70-year-old man presented with chronic visual impairment in his right eye. Visual acuities were $1 / 10$ and 10/10 for the right and left eyes, respectively. Biomicroscopy revealed a nuclear cataract on the right side. Uneventful phacoemulsification was carried out, and a posterior chamber acrylic hydrophobic foldable IOL (Acriva UD613, VSY, Istanbul, Turkey) was implanted. The IOL opacified with a whitish aspect immediately after its implantation in the capsular bag (Figure 1 A). However, the IOL was not changed, and the opacification disappeared by the following day (Figure $1 \mathrm{D}$ ).

Case 2: A 45-year-old woman was admitted with acute visual impairment of her left eye due to a blunt trauma. Visual acuity was consistent with hand motion for the left eye. In addition, she had a mature cataract on the left side. After phacoemulsification, the same IOL (Acriva UD613, VSY) was implanted. Following implantation, it opacified similarly to the previous case (Figure 1 B). The opacification of this IOL had improved a day later (Figure $1 \mathrm{E}$ ).
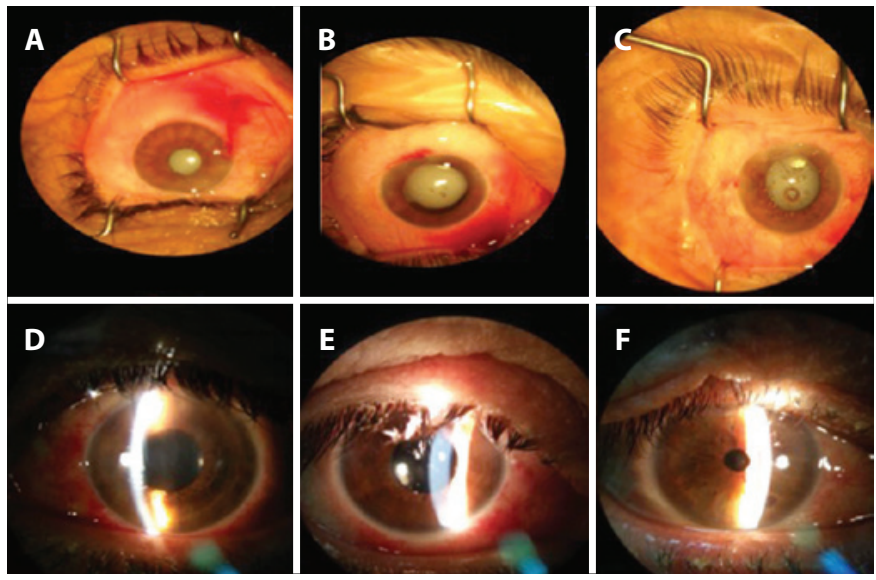

Figure 1. Images of the perioperative opacifications in cases 1 (A), 2 (B), and 3 (C). In addition, the postoperative transparency of the intraocular lenses 1 day after the operation can be seen for cases 1 (D), 2 (E), and 3 (F).
Case 3: A 58-year-old woman was seen owing to chronic visual impairment in her right eye. Visual acuities were 0.05 and 0.9 for the right and left eyes, respectively. Biomicroscopy revealed a posterior subcapsular cataract in her right eye. After performing an uneventful phacoemulsification cataract surgery, the same intraocular IOL (Acriva UD613, VSY) was implanted in the bag. The IOL was clear before the application; however, when it was removed from the pack and implanted into the eye, it became cloudy (Figure $1 \mathrm{C}$ ). Similar to the other cases, the opacification improved the next day (Figure $1 \mathrm{~F}$ ).

Taşkapılı et al. ${ }^{(1)}$ reported the replacement of 28 IOLs (Intraocular Optical International, CA, USA) in 22 patients due to opacification during follow-up. Furthermore, Özçetin et al. ${ }^{(2)}$ reported pseudocataracts in five patients with previous history of cataract operation and posterior chamber IOL implantation, with IOL replacement surgery in four eyes ${ }^{(2)}$. In the abovementioned cases, the pseudocataracts occurred spontaneously due to calcium and phosphate accumulation, which resulted in hydroxyapatite crystal formation ${ }^{(3,4)}$. With regard to the acute opacification of IOLs, Tyagi et al. ${ }^{(5)}$ reported the intraoperative clouding of a hydrophilic IOL caused by changes in temperature. In our cases, phacoemulsification surgery using the divide and conquer technique was uneventful, and it was performed under topical anesthesia. Perioperative viscoelastic sodium hyaluronate (3\%), balanced salt solution, and the intracameral antibiotic cefuroxime (1 mg/0.1 ml) were used. The IOL was made of hydrophobic acrylic material, with a saturation water content of $25 \%$. When the cause of the clouding was investigated, it was found that the IOLs were obtained immediately prior to the operation from the cold store of the hospital pharmacy. Thus, the rapid temperature change caused the opacification of the IOLs. Nonetheless, no permanent structural or mechanical change occurred in the IOLS.

Accordingly, this paper suggests that acute opacification may occur due to rapid temperature change. In light of this knowledge, if this situation occurs during the operation, there is no need to replace the IOL. In addition, appropriate storage of IOLs is still of paramount importance.

\section{ACKNOWLEDGMENT}

I would like to acknowledge the support of Timur Ekiz, MD.

Sezer Helvaci ${ }^{1}$

Submitted for publication: January 21, 2015

Accepted for publication: May 14, 2015

Elbistan State Hospital, Department of Ophthalmology, Kahramanmaraş, Turkey.

Funding: No specific financial support was available for this study.

Disclosure of potential conflicts of interest: The author does not have any potential conflicts of interest to disclose.

Corresponding author: Sezer Helvacı. Elbistan Devlet Hastanesi - Kahramanmaraş - 46100 - Turkey E-mail: sezerhelvaci1985@hotmail.com

\section{REFERENCES}

1. Taşkapılı M, Kocabora S, Kandemir N, Şerefoğlu K, Göçmez E, Yılmazlı C. Göz içi mercek kesifleşmesi olan gözlerde değişim cerrahisi sonuçları. Glo-Kat. 2008;3(1):15-9.

2. Özçetin H, Akova B, Toprak A, Ertürk H, Ipçioğlu A, Bayraktar M. Psödokatarakt olgularımızda klinik. T Oft Gaz. 2006;36:229-33.

3. Tyagi P, Shah N, Jabir M. Intraoperative clouding of a posterior chamber intraocular lens. Int Ophthalmol. 2011;31(6):483-4.

4. Yu AK, ShekTW. Hydroxyapatite formatiın on implanted hydrogel intraocular lenses. Arch Ophthalmol. 2001;119(4):611-4.

5. Yu AK, Kwan KY, Chan DH, Fong DY. Clinical features of 46 eyes with calcified hydrogel intraocular lenses. J Cataract Refract Surg. 2001;27(10):1596-606. 